Mujiono

\title{
Apakah Indeks Saham Syariah Indonesia (ISSI) Memediasi Pengaruh Nilai Tukar terhadap Return Saham Syariah?
}

\author{
Sri Hermuningsih ${ }^{1}$, Hanita Yuniati ${ }^{2}$, Mujino ${ }^{3}$, \\ hermun_feust@yahoo.co.id, hanitajuniati@gmail.com, \\ mujinoust@gmail.com \\ Fakultas Ekonomi Universitas Sarjanawiyata Yogyakarta
}

\begin{abstract}
Abstrak
This study aims to analyze the effect of Exchange Rate on Stock Return with Sharia Stock Index as Mediation.

The population in this study is the sharia shares listing on the Indonesia Stock Exchange. Sampling using purposive sampling method, with criteria List of sharia firms in the Property and Real Estate sectors which are categorized as Sharia (ISSI) Index which is constant (fixed) during December 2015-May 2016 period. Data analysis using regression analysis.

The result of the research shows that the exchange rate has an effect on the Return of Sharia Shares and Sharia Stock Index of Indonesia influential on Sharia Return Shares. Indonesia Sharia Stock Index is able to mediate between Exchange Rate and Sharia Return Shares
\end{abstract}

Keywords : Nilai Tukar, Indeks Saham Syariah Indonesia, Return Saham Syariah.

\section{Pendahuluan}

Saat ini di Indonesia sudah mulai berkembang instrumen keuangan berbasis syariah seperti bank syariah, pasar modal syariah dan pasar komoditi syariah. Bagi emiten mencari dana melalui pasar modal merupakan pilihan pembiayaan (Hermuningsih 2012:3). Salah satunya yaitu Indeks saham syariah Indonesia (ISSI), yang diluncurkan pada 12 Mei 2011 ini berjumlah sebanyak 214 saham syariah. Keberadaan Indeks Saham Syariah Indonesia (ISSI) melengkapi Indeks syariah yang sudah ada sebelumnya yaitu Jakarta Islamic Index (JII). Konstituen Indeks Saham Syariah Indonesia (ISSI) adalah keseluruhan saham syariah yang tercatat di Bursa Efek Indonesia (BEI) dan terdaftar dalam Daftar Efek Syariah (DES). Jumlah investor syariah di BEI bertambah 150\% menjadi 12.283 per akhir 2015 dari 2016 yang hanya sebesar 4.908 (Sumber: www.sahamok.com, diakses 4 Oktober 2017), karena saham syariah ini relatif lebih aman ketimbang berinvestasi di saham non kategori syariah dengan pertimbangan emitennya memenuhi standar syariah, maka relatif lebih aman dan saham syariah tidak lepas dari adanya return saham yang baik. Samsul (2006:291) menjelaskan return saham adalah pendapatan yang dinyatakan dalam persentase dari modal awal investasi. Pendapatan investasi saham ini meliputi jual beli saham, dimana jika untung disebut capital gain dan jika rugi disebut capital loss. Keadaan indeks saham syariah di Indonesia sendiri tidak terlepas dari nilai kurs rupiah terhadap dollar AS yang menjadi salah satu faktor turun naiknya indeks saham di pasar modal Indonesia. Menurut Hanafi (2010:67), harga suatu mata uang relatif terhadap mata uang lainnya (kurs) sangat tergantung dari kekuatan penawaran (supply) dan permintaan (demand) mata uang tersebut. Berdasarkan uraian di atas, penulis tertarik untuk melakukan penelitian yang berjudul 
"Apakah Indeks Saham Syariah Indonesia (Issi) Bisa Memediasi Pengaruh Nilai Tukar Terhadap Return Saham Syariah ?"

\section{Kajian Pustaka dan Pengembangan Hipotesis}

\section{Return Saham Syariah}

Return merupakan salah satu faktor yang memotivasi investor untuk berinvestasi dan juga merupakan imbalan atas keberanian investor dalam menanggung risiko atas investasi yang dilakukan (Tandelilin 2001:45). Menurut Fahmi dan Yovi (2009:151) mengatakan return saham adalah keuntungan yang diperoleh oleh perusahaan, individu dan institusi dari hasil kebijakan investasi yang dilakukannya. Semakin tinggi return saham maka semakin baik investasi yang dilakukan karena dapat menghasilkan keuntungan, sebaliknya semakin return saham atau bahkan negatif maka semakin buruk hasil investasi yang dilakukan. Return saham adalah pendapatan yang dinyatakan dalam persentase dari modal awal investasi. Ada beberapa yang mempengaruhi return sahan syariah yaitu Informasi yang tersedia di pasar modal memiliki peranan yang penting untuk mempengaruhi segala macam bentuk transaksi perdagangan dipasar modal tersebut. Hal ini disebabkan karena para pelaku di pasar modal akan melakukan analisis lebih lanjut terhadap setiap pengumuman atau informasi yang masuk ke bursa efek tersebut, yang diterbitkan oleh emiten akan mempengaruhi para (calon) investor dalam mengambil keputusan.

Berdasarkan pengertian return saham, bahwa return suatu saham adalah hasil yang diperoleh dari investasi dengan cara menghitung selisih harga saham periode berjalan dengan periode sebelumnya dengan mengabaikan deviden, maka dapat ditulis rumus sebagai berikut : (Samsul 2006:291).

$$
\mathrm{Ri}=\frac{P t-P t-1}{P t-1}
$$

Dimana:

$\mathrm{Ri}=$ Return saham

$\mathrm{Pt}=$ Harga saham pada periode $\mathrm{t}$

P t-1 = Harga saham pada periode $\mathrm{t}-1$

\section{Indeks Saham Syariah Indonesia (ISSI)}

Indeks Saham Syariah Indonesia (ISSI) merupakan indeks saham yang mencerminkan keseluruhan saham syariah yang tercatat di Bursa Efek Indonesia (BEI). Pada saat Indeks Saham Syariah Indonesia (ISSI) diluncurkan pada tanggal 12 Mei 2011 di Jakarta, jumlah saham syariah yang tercatat di Bursa Efek Indonesia (BEI) sebanyak 214 saham. Keberadaan Indek Saham Syariah Indonesia (ISSI) melengkapi indeks syariah yang sudah ada sebelumnya yaitu Jakarta Islamic Index (JII). Konstituen ISSI adalah keseluruhan saham syariah tercatat di Bursa Efek Indonesia (BEI) dan terdaftar dalam Daftar Efek Syariah (DES). Konstituen Indeks Saham Syariah Indonesia (ISSI) direview setiap 6 bulan sekali (Mei dan November) dan dipublikasikan pada awal bulan berikutnya. Konstituen ISSI juga dilakukan penyesuaian apabila ada saham syariah yang baru tercatat atau dihapuskan dari Daftar Efek Syariah (DES). Metode perhitungan indeks ISSI menggunakan ratarata tertimbang dari kapitalisasi pasar. Tahun dasar yang 
Mujiono

digunakan dalam perhitungan Indeks Saham Syariah Indonesia (ISSI) adalah awal penerbitan Daftar Efek Syariah (DES) yaitu Desember 2007. (Sumber: www.sahamok.com, diakses 4 Oktober 2017). Data Indeks Saham Syariah Indonesia didapatkan dari laporan ringkasan indeks Bursa Efek Indonesia dengan jenis data bulanan dan skala prosentase. Saham-saham yang tergolong dalam Indeks Saham Syariah Indonesia (ISSI) merupakan saham yang telah memenuhi kriteria sebagai sebagai saham syariah dan dirangkum didalam Daftar Efek Syariah (DES) yang diterbitkan oleh Bapepam-LK. Menurut Jogiyanto (2009:100) suatu indeks saham diperlukan sebagai sebuah indikator untuk mengamati pergerakan harga dari sekuritas-sekuritasyang dimiliki BEI sampai sekarang seperti Indeks Harga Saham Gabungan (IHSG), Liquid Index 45 (LQ-45), Jakarta Islamic Index (JII), Indeks Saham Syariah Indonesia (ISSI), Indeks Papan Utama dan Indeks Papan Pengembangan, serta Indeks Kompas 100.

\section{Nilai Tukar (Kurs)}

Nilai tukar adalah harga sebuah mata uang dari suatu negara, yang diukur atau dinyatakan dalam mata uang lainnya. Menurut Hanafi (2010:67), harga suatu mata uang relatif terhadap mata uang lainnya (kurs) sangat tergantung dari kekuatan penawaran (supply) dan permintaan (demand) mata uang tersebut. Nilai tukar mata uang dipercayakan bisa membantu investor dalam meramalkan apa yang akan terjadi dipasar modal, termasuk di Indonesia. Investor dapat melihat fluktuasi nilai tukar valuta asing dengan indikator Kurs Bank Indonesia (Kurs Jual, Kurs Beli dan Kurs Tengah Bank Indonesia). Sedangkan Menurut Sukirno (2012:402), ada beberpa faktoryang dapat mempengaruhi kurs yaitu Perubahan cita rasa masyarakat akan mengubah corak konsumsinya atas barang-barang yang diproduksi didalam maupun diluar negeri, perubahan harga barang ekspor dan impor akan menyebabkan perubahan dalam permintaan dan penawaran valuta asing, Kenaikan harga umum (inflasi), Suku bunga dan tingkat pengembalian investasi serta dalam Pertumbuhan ekonomi. Sifat dari kurs valuta asing tergantung sifat pasar. Apabila transaksi jual beli valuta asing dapat dilakukan secara bebas di pasar, maka kurs valuta asing akan berubah-ubah sesuai dengan perubahan permintaan dan penawaran Dalam penelitian ini indikator yang digunakan adalah Kurs Tengah Bank Indonesia dengan rumusan yang di kemukakan oleh (Joko Salim 2008 : 45) sebagai berikut:

$$
\text { Kurs Tengah }=\frac{\text { Kurs Jual }+ \text { Kurs Beli }}{2}
$$

\section{Pengembangan Hipotesis}

\section{Pengaruh nilai tukar terhadap Indeks Saham Syariah Indonesia (ISSI)}

Nilai tukar merupakan salah satu variabel yang mampu mempengaruhi pergerakan indeks harga saham pada pasar modal. Nilai tukar yang mengalami depresiasi akan memberikan dampak yang berbeda bagi perusahaan - perusahaan dalam kategori perusahaan impor ataupun perusahaan ekspor. Pada saat nilai tukar mengalami kenaikan yang akan berpengaruh terhadap kenaikan harga pada umumnya terkait dengan sejumlah uang, dan nilai tukar mata uang ini bersifat stabil dan bisa juga labil atau terlalu bergerak naik atau turun. Dengan adanya kenaikan nilai tukar tersebut akan menimbulkan penilaian dibenak para investor bahwa Indeks Saham 
Mujiono

Syariah Indonesia (ISSI) mengalami kenaikan permintaan dan penjualan tersebut baik, dengan begitu banyak investor yang akan tertarik dan mau menanamkan modalnya, sehingga permintaan Indeks Saham Syariah Indonesia (ISSI) meningkat dan sudah tentu volume perdagangan saham syariah (ISSI) menaik. Penelitian yang dilakukan oleh Rega Saputra (2017),” Pengaruh Bi Rate, Inflasi, Nilai Tukar Rupiah, Dan Sertifikat Bank Indonesia Syariah (Sbis) Terhadap Indeks Saham Syariah Indonesia (Issi) periode Juni 2011 hingga Mei 2015”. Dengan hasil penelitian menyatakan bahwa Nilai Tukar Rupiah berpengaruh signifikan terhadap Indeks Saham Syariah Indonesia (ISSI) periode Juni 2011 hingga Mei 2015.

H1 : Nilai tukar berpengaruh terhadap Indeks Saham Syariah Indonesia (ISSI)

\section{Pengaruh Indeks Saham Syariah Indonesia (ISSI) terhadap Return saham syariah}

Indeks Saham Syariah Indonesia (ISSI) merupakan indeks saham yang mencerminkan keseluruhan saham syariah yang tercatatdi BEI. Konstituen ISSI adalah keseluruhan saham syariah tercatat di BEI dan terdaftar dalam Daftar Efek Syariah (DES). Konstituen Indeks Saham Syariah Indonesia (ISSI) direview setiap 6 bulan sekali dan di publikasikan pada awal bulan berikutnya. Konstituen Indeks Saham Syariah Indonesia juga di perbaharui jika ada saham syariah yang baru tercatat atau dihapuskan dari DES. Dengan pertimbangan untuk meminimalisir kerugian itulah Indeks Saham Syariah Indonesia (ISSI) kini mengalami peningkatan yang signifikan dengan bertambahnya jumlah investor syariah di BEI bertambah 150\% menjadi 12.283 per akhir 2016 dari 2015 yang hanya sebesar 4.908 (Sumber: www.sahamok.com, diakses 4 Oktober 2017), karena saham syariah ini relatif lebih aman ketimbang berinvestasi di saham non kategori syariah dengan pertimbangan emitennya memenuhi standar syariah, maka relatif lebih aman dan saham syariah tidak lepas dari adanya suku bunga yang renda serta return saham yang baik saat ini. Pendapat ini di perkuat dengan penelitian yang di lakukan Ahmad Fajri (2016), "Pengaruh Indeks Bursa Saham Syariah Asing Dan Variabel Makro Ekonomi Terhadap Indeks Saham Syariah Indonesia" dengan hasil variabel Dow Jones Islamic Market Japan, Dow Jones Islamic Market Malaysia dan nilai tukar rupiah memiliki pengaruh signifikan terhadap Indeks Saham Syariah Indonesia ISSI.

H2 : Indeks Saham Syariah Indonesia (ISSI) berpengaruh terhadap return Saham Syariah

\section{Pengaruh nilai tukar (kurs) secara tidak langsung terhadap Return saham syariah melalui Indeks Saham Syariah Indonesia (ISSI)}

Indeks Saham Syariah Indonesia (ISSI) sendiri tidak lepas dari nilai kurs rupiah terhadap dollar AS yang menjadi salah satu faktor turun naiknya indeks saham di pasar modal Indonesia yang berdampak terhadap nilai return saham pada perusahaan yang terdaftar di BEI. Berdasarkan pendekatan hukum permintaan dan penawaran, nilai tukar rupiah yang melemah terhadap dolar membuat harga dari dolar akan menjadi lebih mahal dari nilai nominalnya ini disebabkan permintaan terhadap dolar melebihi jumlah yang ditawarkan, atau jumlah permintaan tetap sementara penawaran terhadap dolar jumlahnya berkurang. Situasi yang berbeda ditunjukkan saat rupiah mengalami penguatan terhadap dolar maka harga dolar akan diilai lebih murah dari harga nominal atau harga berlakunya, hal ini disebabkan jumlah permintaan yang sedikit sementara penawaran terhadap dolar yang bertambah banyak, atau permintaan terhadap dolar semakin 
Mujiono

menurun saat jumlah penawaran tetap. Pada mekanisme pasar, nilai tukar akan mencapai titik keseimbangan saat bertemunya jumlah permintaan dan penawaran mata uang tersebut di titik yang sama. Saat nilai tukar rupiah menguat terhadap dolar, maka permintaan terhadap jumlah dolar akan semakin meningkat, atau sebaliknya. Penelitian ini di dukung oleh Akbar Faoriko (2013) "Pengaruh Inflasi, Suku Bunga Dan Nilai Tukar Rupiah, Terhadap Return Saham Di Bursa Efek Indonesia “. Dengan hasil penelitian menyatakan bahwa Nilai Tukar Rupiah tidak berpengaruh negatif dan signifikan terhadap Return Saham pada perusahaan manufaktur yang terdaftar di BEI periode 2008-2010.

H3 : Nilai tukar berpengaruh secara tidak langsung terhadap return saham syariah melalui Indeks Saham Syariah Indonesia (ISSI).

\section{Kerangka Pikir Penelitian}

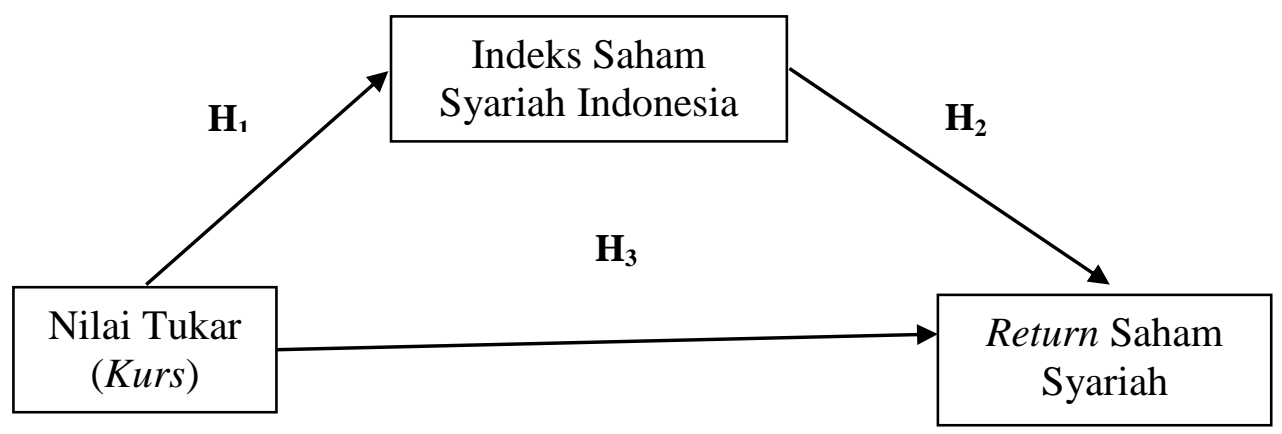

Gambar 1 Kerangka Pikir Penelitian

\section{Metode Penelitian}

\section{Definisi Operasional}

\section{Return Saham Syariah}

Return saham adalah hasil yang diperoleh dari investasi dengan cara menghitung selisih harga saham periode berjalan dengan periode sebelumnya dengan mengabaikan deviden, maka dapat ditulis rumus sebagai berikut :(Samsul 2006:291)

$$
\mathrm{Ri}=\frac{P t-P t-1}{P t-1}
$$

Dimana:

$\mathrm{Ri}=$ Return saham

$\mathrm{Pt}=$ Harga saham pada periode $\mathrm{t}$

$\mathrm{P} \mathrm{t}-1$ = Harga saham pada periode $\mathrm{t}-1$ 
Sri Hermuningsih

Hanita Yuniati

Mujiono
Jurnal Manajemen Bisnis Indonesia

Vol. 4, Nomor 2, Feb 2017

\section{Indeks Saham Syariah Indonesia (ISSI)}

Indeks Saham Syariah Indonesia (ISSI) merupakan indeks saham yang mencerminkan keseluruhan saham syariah yang tercatat di Bursa Efek Indonesia (BEI) dan direview setiap 6 bulan sekali (Mei dan November) dan dipublikasikan pada awal bulan berikutnya. (Sumber: www.sahamok.com, diakses 4 Oktober 2017).

\section{Nilai Tukar (Kurs)}

Nilai tukar merupakan harga didalam pertukaran dua macam mata uang yang berbeda, akan terdapat perbandingan nilai atau harga antara kedua mata uang tersebut. Nilai tukar mata uang dipercayakan bisa membantu investor dalam meramalkan apa yang akan terjadi dipasar modal, termasuk di Indonesia. Investor dapat melihat fluktuasi nilai tukar valuta asing dengan indikator Kurs Bank Indonesia (Kurs Jual, Kurs Beli dan Kurs Tengah Bank Indonesia). Dalam penelitian ini indikator yang digunakan adalah Kurs Tengah Bank Indonesia dengan rumusan yang dikemukakan oleh Joko Salim (2008 : 45) sebagai berikut :

$$
\text { Kurs Tengah }=\frac{\text { Kurs Jual }+ \text { Kurs Beli }}{2}
$$

\section{Populasi, Sampel dan Teknik Pengambilan Sampel}

Populasi dalam penelitian ini adalah saham syariah yang listing di Bursa Efek Indonesia (BEI). Sampel pada penelitian ini adalah saham syariah yang termasuk kategori Indeks Saham Syariah Indonesia (ISSI) sektor property dan Real Estate yang listing di Bursa Efek Indonesia (BEI).

\section{Teknik Pengambilan Sampel}

Pengambilan sampel dengan metode purposive sampling, dengan kriteria sampel adalah sebagai berikut:

a) Daftar perusahaan syariah sektor Property dan Real Estate yang termasuk kategori Indeks Saham Syariah (ISSI) yang konstan (tetap) selama periode Desember 2015-Mei 2016.

b) Tercatat di Indeks Saham Syariah Indonesia (ISSI) pada periode Desember 2015-Mei 2016 yang tidak keluar masuk selama perhitungan Indeks Saham Syariah Indonesia (ISSI).

\section{Data}

Data yang digunakan merupakan data sekunder yang diperoleh dari data historis yang dipublikasikan melalui website www.bi.go.id, www.bps.go.id, www.sahamok.com dan 
Mujiono

www.duniainvestasi.co.id. Data yang digunakan untuk penelitian ini merupakan harga penutup bulanan yang akan digunakan untuk menghitung Return bulanan.

\section{Hasil dan Pembahasan}

Hasil analisis statistik deskriptif terhadap variabel-variabel pada penelitian ini secara ringkas disajikan pada tabel berikut ini.

\section{Statistik Deskriptif}

\section{Tabel 1}

Descriptive Statistics Selama Periode 2015-2016

Descriptive Statistics

\begin{tabular}{|l|r|r|r|r|r|}
\hline & \multicolumn{1}{|c|}{ N } & Minimum & Maximum & Mean & Std. Deviation \\
\hline NT & 114 & 15.08 & 34.39 & 25.0095 & 4.74944 \\
ISSI & 114 & 14.06 & 36.02 & 24.0844 & 4.43170 \\
Return & 114 & 11.48 & 28.22 & 20.6269 & 4.10421 \\
Valid N (listwise) & 114 & & & & \\
\hline
\end{tabular}

Berdasarkan hasil statistik deskriptif yang telah disajikan dalam tabel 1 dapat diketahui masing-masing variabel sebagai berikut:

1. Variabel Nilai Tukar berdasarkan tabel di atas statistik deskriptif Nilai Tukar mempunyai nilai minimum 15,08 , nilai maksimum 34,39 , rata-rata (mean) 25,00 dan standar deviasi 4,74.

2. Berdasarkan tabel statistik deskriptif Indeks Saham Syariah Indonesia(ISSI) memiliki nilai minimum 14,06 nilai maksimum 36,02, rata-rata (mean) 24,08 dan standar deviasi 4,43 .

3. Berdasarkan tabel statistik deskriptif Return Saham Syariah memiliki nilai minimum 11,48 nilai maksimum 28,22, rata-rata (mean) 20,62 dan standar deviasi 4,10.

\section{Uji Asumsi}

Terdapat beberapa tahap dalam melakukan uji asumsi klasik yakni :

\section{a. Uji Normalitas Data}

Uji normalitas bertujuan untuk menguji apakah model regresi, Variabel terikat dan variabel bebas keduanya memilki distribusi normal atau tidak. Model yang baik adalah mempunyai distribusi data normal atau mendekati normal. Dalam penelitian ini, uji normalitas digunakan uji grafik dan uji Statistik.

1. Uji Grafik

Berdasarkan hasil olah data dapat dilihat uji grafik normalitas pada gambar 1 sebagai berikut : 
Sri Hermuningsih

Hanita Yuniati

Mujiono
Jurnal Manajemen Bisnis Indonesia

Vol. 4, Nomor 2, Feb 2017

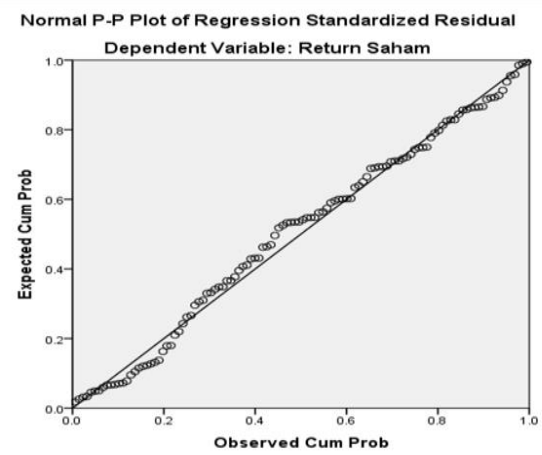

Gambar 1. Normal P-P Plot

\section{Uji Statistik}

Uji normalitas dengan uji statistik dalam penelitian ini menggunakan uji Kolmogorov Smirnov dan uji Shapiro-Wilk. Berdasarkan perhitungan uji normalitas terdapat pada tabel 2 dibawah ini:

Tabel 2. Tests of Normality

\begin{tabular}{ccl}
\hline Kolmogorov-Smirnov $^{\mathrm{a}}$ & Shapiro-Wilk & Keterangan \\
\hline Sig & Sig & \\
\hline $.200^{*}$ & .216 & $\begin{array}{l}\text { Data Terdistribusi } \\
\text { Normal }\end{array}$ \\
& & .
\end{tabular}

Sumber : Data yang diolah, 2018

Berdasarkan tabel diatas menunjukkan bahwa nilai sig Kolmogorov-Smirnov sebesar 0,200 dan nilai sig Shapiro-Wilk sebesar 0,261, lebih besar dari 0,05 dengan hasil ini berarti data berdistribusi normal.

\section{b. Uji Multikolinearitas}

Pengujian multikolinearitas bertujuan untuk mengetahui ada tidaknya hubungan tumpang tindih antar variabel bebas. Uji multikolinearitas dilakukan dengan melihat Tolerance dan VIF. Apabila diperoleh tolerance mendekati 1, dan VIF tidak lebih dari 10, maka disimpulkan tidak terjadi multikolinearitas. 
Mujiono

Tabel 3

Nilai Uji Multikonearitas

\begin{tabular}{lrrl}
\hline & \multicolumn{3}{c}{ Coefficients } \\
\hline Model & Tolerance & VIF & Keterangan \\
\hline NT & .823 & 1.21 & Tidak Terjadi Masalah Multikolinearitas \\
& & 5 & Tidal Terjadi Masalah Multikolinearitas \\
\hline ISSI & .532 & 1.88 & \\
& & 0 & \\
\hline
\end{tabular}

Sumber : Data yang diolah, 2018

Dari hasil olah data pada tabel 3 di atas, dapat dilihat nilai VIF semua variabel bebas memiliki nilai VIF $<10$ dan nilai Tolerance $<1$, sehingga model regresi tersebut di atas tidak terjadi multikolinieritas sehingga model regresinya dapat digunakan.

\section{c. Uji Heteroskedastisitas}

Uji heterokedasitas yang digunakan dalam penelitian ini adalah uji Gleser, kemudian dengan berpedoman pada taraf signifikan $\alpha=0.05$. Hasil perhitungan dapat dilihat dalam tabel 4 berikut ini :

\section{Tabel 4}

Nilai Uji Heteroskedastisitas

\begin{tabular}{lll}
\hline Model & Sig. & Keterangan \\
\hline NT & .601 & Tidak Terjadi Gejala Heteroskedastisitas \\
ISSI & .653 & Tidak Terjadi Gejala Heteroskedastisitas \\
\hline
\end{tabular}

Sumber : Data yang diolah, 2018

Hasil Uji diatas diperoleh bahwa seluruh nilai variabel bebas mempunyai nilai probabilitas (sig) yang lebih besar dari taraf signifikan 0,05, Sehingga dapat disimpulkan bahwa dalam model regresi menunjukkan bahwa tidak terjadi gejala heteroskedastisitas.

\section{d. Uji Autokorelasi}

Identifikasi secara statistik ada tidaknya gejala autokorelasi dapat dilakukan dengan menghitung nilai Durbin-Watson (dw). Hasil uji autokorelasi dengan Durbin-Watson terlihat pada tabel sebagai berikut : 


\section{Tabel 5}

Nilai Uji Autokorelasi

\begin{tabular}{|c|c|c|c|c|c|}
\hline Model & $\mathrm{R}$ & R Square & $\begin{array}{l}\text { Adjusted R } \\
\text { Square }\end{array}$ & $\begin{array}{l}\text { Std. Error of the } \\
\text { Estimate }\end{array}$ & Durbin-Watson \\
\hline 1 & $.546^{\mathrm{a}}$ & .298 & .279 & 3.466 & 1.839 \\
\hline
\end{tabular}

Berdasarkan tabel diatas, hasil pengujian diperoleh nilai Durbin-Watson sebesar 1.839. Nilai tersebut kemudian dibandingkan dengan nilai du dan 4-du. Nilai du diambil dari tabel DW dengan $\mathrm{N}=114$ dan $\mathrm{k}=1$ sehingga diperoleh du sebesar 1.522. kemudian dilakukan pengambilan keputusan dengan ketentuan $\mathrm{du}<\mathrm{d} \leq 1-\mathrm{du}(1.522<1,839 \leq 4-1.522)$. Hal ini bearti tidak terjadi autokorelasi antara variabel independen sehingga model layak digunakan.

\section{Pengujian Hipotesis}

\section{Uji t (Parsial)}

\section{Pengaruh nilai tukar terhadap Indeks Saham Syariah Indonesia (ISSI) $\mathbf{H}_{1}$}

Pengujian hipotesis 1 menggunakan uji t yang dilakukan untuk melihat pengaruh nilai tukar (Kurs) terhadap Indeks Saham Syariah Indonesia (ISSI). Uji ini dapat dilakukan dengan melihat kolom signifikansi pada tabel 2

\section{Table 6}

\section{Hasil Nilai (Uji t) Model 1}

\begin{tabular}{llcl}
\hline & \multicolumn{3}{c}{ Coefficients } \\
\hline & $\mathrm{T}$ & Sig. & Keterangan \\
\hline Constant $)$ & 3.592 & .000 & Berpengaruh Positif \\
$\mathrm{H}_{1} \mathrm{NT}$ & 2.201 & .030 & Berpengaruh Positif \\
\hline
\end{tabular}

Sumber : Data diolah, 2018

$\mathrm{H}_{0} \quad$ artinya variabel nilai tukar secara parsial tidak mempunyai pengaruh terhadap variabel Indeks Saham Syariah Indonesia (ISSI)

$\mathrm{H}_{1} \quad$ artinya variabel nilai tukar secara parsial mempunyai pengaruh terhadap variabel Indeks Saham Syariah Indonesia (ISSI)

Dengan kriteria pengambilan keputusan sebagai berikut :

Ho diterima apabila t-hitung $<\mathrm{t}$-tabel

H1 diterima apabila t-hitung $>$ t-tabel 
Mujiono

Dan dalam analisis ini uji t dilakukan pada derajat kebebasan $(n-k-1)=114-2-1=111$, dimana $\mathrm{n}$ adalah jumlah sampel dan $\mathrm{k}$ adalah jumlah variabel. Dan pada tingkat keyakinan $95 \%$ atau $\alpha=5 \%$.

Berdasarkan hasil olah data variabel nilai tukar memiliki, t-hitung lebih besar dari t-tabel $(2.201>1.28930)$ dengan probabilitas $(0,030)$ yang artinya nilai probabilitas lebih kecil dari taraf signifikan 0,05, dengan demikian Ho ditolak dan H1 diterima, artinya nilai tukar secara parsial mempunyai pengaruh terhadap variabel Indeks Saham Syariah Indonesia (ISSI).

\section{Pengaruh Indeks Saham Syariah Indonesia (ISSI) terhadap return saham syariah $\mathbf{H}_{2}$}

Pengujian hipotesis 2, menggunakan uji t yang dilakukan untuk melihat pengaruh Indeks Saham Syariah Indonesia (ISSI) terhadap return saham syariah. Uji ini dapat dilakukan dengan melihat kolom signifikansi pada tabel

\section{Table 7}

Hasil Nilai (Uji t) Model 2

\begin{tabular}{llll}
\hline & \multicolumn{3}{c}{ Coefficients } \\
\hline & T & Sig. & Keterangan \\
\hline (Constant) & 2.926 & .004 & Berpengaruh Positif \\
H2 ISSI & 3.572 & .001 & Berpengaruh Positif \\
\hline
\end{tabular}

Sumber : Data diolah, 2018

$\mathrm{H}_{0}$

artinya variabel Indeks Saham Syariah Indonesia (ISSI) secara parsial tidak mempunyai pengaruh terhadap variabel return saham syariah

$\mathrm{H}_{1} \quad$ artinya variabel Indeks Saham Syariah Indonesia (ISSI) secara parsial mempunyai pengaruh terhadap variabel return saham syariah

Dengan kriteria pengambilan keputusan sebagai berikut :

Ho diterima apabila t-hitung $<\mathrm{t}$-tabel

H1 diterima apabila t-hitung $>\mathrm{t}$-tabel

Dan dalam analisis ini uji t dilakukan pada derajat kebebasan $(n-k-1)=114-3-1=110$, dimana $\mathrm{n}$ adalah jumlah sampel dan $\mathrm{k}$ adalah jumlah variabel. Dan pada tingkat keyakinan $95 \%$ atau $\alpha=5 \%$. Berdasarkan hasil olah data variabel indeks saham syariah indonesia (ISSI) t-hitung lebih besar dari t-tabel (3.572>1.65895) dengan probabilitas (.001) yang artinya nilai probabilitas lebih kecil dari taraf signifikan 0,05, dengan demikian H1 diterima dan Ho ditolak, artinya variabel Indeks Saham Syariah Indonesia (ISSI) memiliki pengaruh terhadap return saham syariah dalam penelitian ini. 
Sri Hermuningsih

Hanita Yuniati

Mujiono
Jurnal Manajemen Bisnis Indonesia

Vol. 4, Nomor 2, Feb 2017

\section{Analisis Jalur}

a. Berdasarkan hasil regresi diatas maka Estimasi Parameter Model dapat di lihat pada tabel 4, untuk pengujian hipotesis ketiga sebagai berikut :

\section{Tabel 8}

Hasil Estimasi Parameter Model

\begin{tabular}{|c|c|c|c|}
\hline \multicolumn{4}{|c|}{ Model } \\
\hline \multicolumn{4}{|c|}{ Sub Structural $1\left(\mathrm{X}_{1}\right.$ ke $\left.\mathrm{Y}\right)$} \\
\hline & Beta & Sig & $\mathrm{R}^{2}$ \\
\hline $\mathrm{X}_{1}\left(\mathrm{p} \mathrm{Y}, \mathrm{X}_{1}\right)$ & .164 & .030 & .468 \\
\hline \multicolumn{4}{|c|}{ Sub Structural $1\left(\mathrm{X}_{1} \mathrm{Y}\right.$ ke $\left.\mathrm{Z}\right)$} \\
\hline & Beta & Sig & $\mathrm{R}^{2}$ \\
\hline $\mathrm{X}_{1}\left(\mathrm{p} \mathrm{Z}, \mathrm{X}_{1}\right)$ & .210 & .019 & .279 \\
\hline $\mathrm{Z}(\mathrm{p} Z, \mathrm{Y})$ & .391 & .001 & \\
\hline
\end{tabular}

Sumber : Data diolah, 2018

Dari tabel 4 di atas, Estimasi Parameter Model untuk Structural satu menunjukkan bahwa nilai koefisien regresi nilai tukar kurs terhadap Indeks Saham Syariah Indonesia (ISSI) sebesar 0.164 dengan nilai signifikansi 0.030. Sehingga nilai tukar (kurs) berpengaruh langsung terhadap Indeks Saham Syariah Indonesia (ISSI). Estimasi Parameter Model untuk Structural dua menunjukkan bahwa nilai koefisien regresi Indeks Saham Syariah Indonesia (ISSI) terhadap return saham syariah sebesar 0.391 dengan nilai signifikansi 0.001 , kemudian untuk koefisien regresi nilai tukar kurs terhadap return saham syariah sebesar 0.210 dengan nilai signifikansi 0.019 .

1. Berdasarkan hasil regresi maka dapat digambarkan model analisis jalur untuk hipotesis ketiga seperti pada gambar 2 sebagai berikut :

Gambar 2

Analisis Jalur $\mathbf{H}_{3}$

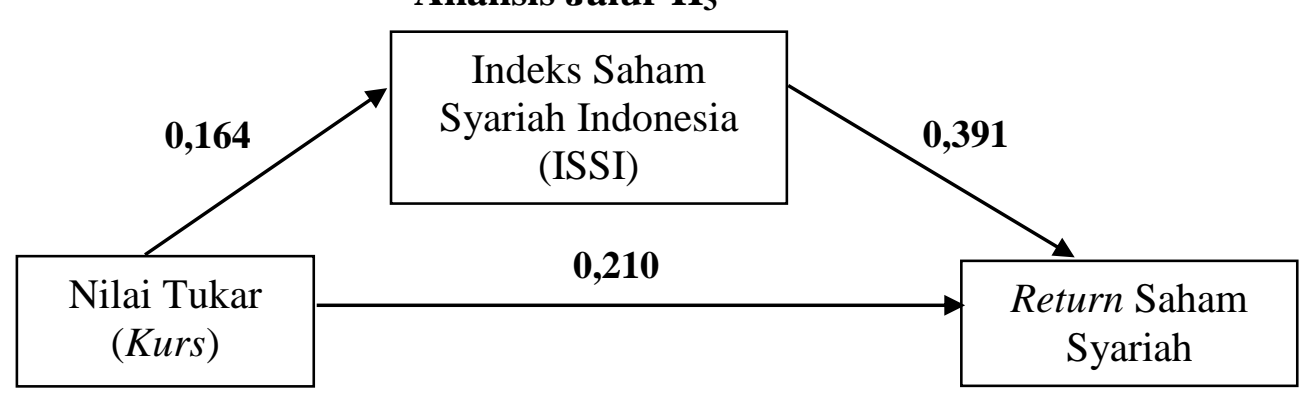


Sri Hermuningsih

Hanita Yuniati

Mujiono
Jurnal Manajemen Bisnis Indonesia

Vol. 4, Nomor 2, Feb 2017

Keterangan:

\section{a) Pengaruh langsung}

1. Pengaruh varibel nilai tukar (kurs) terhadap Return Saham Syariah Koefisien Beta $\mathrm{X}_{1} \rightarrow \mathrm{Y}=0,210$.

2. Pengaruh variabel nilai tukar (kurs) terhadap Indeks Saham Syariah Indonesia (ISSI), Koefisien Beta $Z \rightarrow Y=0,164$.

3. Pengaruh variabel Indeks Saham Syariah Indonesia (ISSI) terhadap Return Saham Syariah Koefisien Beta $Z \rightarrow Y=0,391$.

b) Pengaruh tidak langsung

1. Pengaruh variabel nilai tukar (kurs) terhadap Return Saham Syariah melalui Indeks Saham Syariah Indonesia (ISSI) sebagai berikut : nilai tukar (kurs) $\rightarrow$ ISSI $\rightarrow$ Return Saham Syariah $=(0,164 \times 0,391)=0,0641$

\section{c) Pengaruh total}

1. Pengaruh variabel nilai tukar kurs terhadap Return Saham Syariah melalui Indeks Saham Syariah Indonesia (ISSI) sebagai berikut : nilai tukar (kurs) $\rightarrow$ ISSI $\rightarrow$ Return Saham Syariah $=(0,210+0,064)=0,274$

Dari analisis jalur untuk hipotesis ketiga, dapat dilihat ada pengaruh signifikan nilai tukar (kurs) secara langsung terhadap Return Saham Syariah dan pengaruh tidak langsung nilai tukar kurs terhadap Return Saham Syariah melalui Indeks Saham Syariah Indonesia (ISSI). Sehingga perlu dilakukan uji sobel (sobel test) pada pengaruh tidak langsung antara nilai tukar kurs terhadap Return Saham Syariah melalui Indeks Saham Syariah Indonesia (ISSI) agar dapat diketahui apakah variabel Indeks Saham Syariah Indonesia (ISSI), secara signifikan mampu memediasi (intervening). Berikut adalah perhitungan sobel test dengan menggunakan rumus sobel test calculator :

\section{Gambar 3}

\section{Perhitungan Sobel Test $\mathbf{H}_{4}$}

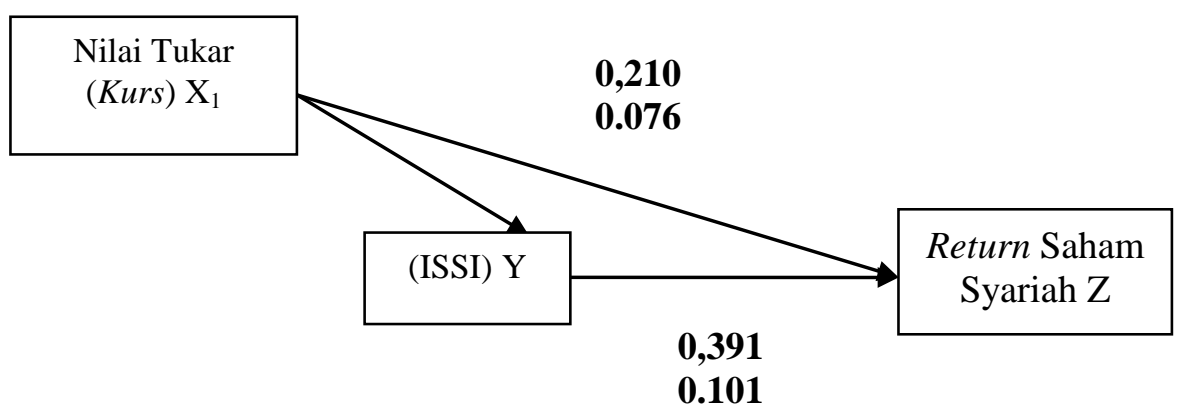


Sri Hermuningsih

Hanita Yuniati

Mujiono
Jurnal Manajemen Bisnis Indonesia

Vol. 4, Nomor 2, Feb 2017

Keterangan :

koefisien regresi variabel independen terhadap mediasi.

koefisien regresi variabel mediasi terhadap dependen.

Ea standard error of estimation dari pengaruh variabel independen terhadap variabel mediasi.

standard error of estimation dari pengaruh variabel mediasi

$E b$ terhadap variabel dependen.

$$
r=\frac{a b}{\sqrt{\mathrm{b} 2 \mathrm{SEa} 2++\mathrm{b} 2 \mathrm{SEb} 2}}
$$

Tabel 9

Hasil Sobel Test Calculator

\begin{tabular}{cc}
\hline \multicolumn{2}{c}{ Sobel Test Calculator } \\
\hline $\mathrm{A}$ & 0,210 \\
$\mathrm{~B}$ & 0,391 \\
$S E a$ & 0.076 \\
$S E b$ & 0.101 \\
\hline Sobel test & $2,249.03$ \\
statistic & 644615 \\
\hline
\end{tabular}

Sumber : Olah data 2017 pada Sobel Test Calculator (http://www.danielsoper.com).

Dari hasil perhitungan diatas nilai Y pada pengaruh tidak langsung antara nilai tukar kurs terhadap Return Saham Syariah melalui Indeks Saham Syariah Indonesia (ISSI), sebesar 2, 249. Nilai z 2,249 lebih besar (>) dari nilai t tabel 1.65895 dengan tingkat signifikansi 0,05 sehingga dapat disimpulkan bahwa Indeks Saham Syariah Indonesia (ISSI), mampu memediasi pengaruh nilai tukar (kurs) terhadap Return Saham Syariah.

\section{Kesimpulan} antara lain:

Berdasarkan hasil analisis data dan pembahasan, dapat diambil beberapa kesimpulan,

1. Nilai tukar secara parsial mempunyai pengaruh terhadap variabel Indeks Saham Syariah Indonesia (ISSI) Pada sektor Property dan Real Estate selama periode Desember 2015Mei 2016. Hal ini menu njukkan bahwa apabila Nilai Tukar Rupiah Naik maka investasi saham di sector property dan Real Estate Pada Indeks Saham Syariah Indonesia akan meningkat. 
Sri Hermuningsih

Hanita Yuniati

Mujiono
Jurnal Manajemen Bisnis Indonesia

Vol. 4, Nomor 2, Feb 2017

2. Variabel Indeks Saham Syariah Indonesia (ISSI) pengaruh positif dan signifikan terhadap return saham syariah Pada sektor Property dan Real Estate selama periode Desember 2015-Mei 2016

3. Nilai tukar (kurs) berpengaruh positif signifikan terhadap Return saham syariah melalui Indeks Saham Syariah Indonesia (ISSI) Pada sektor Property dan Real Estate selama periode Desember 2015-Mei 2016

\section{Daftar Pustaka}

Ahmad Fajri (2016),"Pengaruh Indeks Bursa Saham Syariah Asing Dan Variabel Makro Ekonomi Terhadap Return Indeks Saham Syariah Indonesia".E-Journal UIN Jakarta_6,8, 2016.

Faoriko, Akbar, 2013. Pengaruh Inflasi, Suku Bunga dan Nilai Tukar Rupiah, Terhadap Return Saham di Bursa Efek Indonesia, http://eprints.uny.ac.id/16422/1/lengkap\%20finis.pdf (16 Januari 2016).

Hanafi, Mamduh M. (2010). Manajemen Keuangan. Edisi Pertama. Yogyakarta: BPFE. hal 67

Hartono, Jogiyanto. (2009). Teori Portofolio dan Analisis Investasi, Edisi Keenam Cetakan Pertama. Yogyakarta: BPFE. hal 100

Hermuningsih, Sri. (2012). Pengantar Pasar Modal Indonesia. Yogyakarta.: UPP STM YKPN. hal 3

Irham Fahmi \& Yovi L Hadi. (2009). Teori Portofolio dan Analisis Investasi. Bandung: Alfabeta. hal 151

Joko Salim, 2008. Mengikuti Jejak Bisnis Menggiurkan Orang Tionghoa. Jakarta : Transmedia Pustaka. hal 45

Mohamad Samsul. (2006). Pasar Modal dan Manajemen Portofolio, Edisi pertama. Jakarta: Erlangga. hal 291

Sukirno, Sadono. (2012). Makro Ekonomi, Teori Pengantar. Penerbit PT. Raja Grafindo Persada, Jakarta. hal 402

Saputra, Rega (2017),” Pengaruh Bi Rate, Inflasi, Nilai Tukar Rupiah, Dan Sertifikat Bank Indonesia Syariah (Sbis) Terhadap Indeks Saham Syariah Indonesia (Issi) periode Juni 2011 hingga Mei 2015. UIN Raden Fatah Palembang.

Tandelilin. (2001). ANALISIS Investasi dan Manajemen Portofolio Edisi Pertama. Yogyakarta: BPFE Yogyakarta. hal 45

Undang-undang Republik Indonesia Nomor 8 Tahun 1995 tentang Pasar Modal

$\underline{\text { www.sahamok.com }}$

www.bi.go.id,

www.bps.go.id

www.duniainvestasi.co.id. 